\title{
Original Research \\ In situ Bioremediation of Heavy Metals in Contaminated Soil Using Microbial Agents and Planting Experiments
}

\author{
Qiwei Zhan ${ }^{1,2}$, Chunxiang Qian ${ }^{1,2 *}$, Mingming Wang ${ }^{1,2}$ \\ 'School of Materials Science and Engineering, \\ ${ }^{2}$ Research Institute of Green Construction Materials, \\ Southeast University, Jiulonghu Campus, Nanjing 211189, P.R. China
}

Received: 25 November 2014

Accepted: 27 January 2015

\begin{abstract}
In this paper, two kinds of microbial agents - carbonate-microbe agents (CMA) and phosphate-microbe agents (PMA) - were used to remedy heavy metals in contaminated soil. Contrastive analysis of the remedying effects by CMA and PMA was obtained. Meanwhile, green vegetable cultivation and a vegetable transplanting experiment were conducted in contaminated soil that had been remedied by two kinds of microbial agents. The planting experiment clearly contributed to analysis of the remedying effect. The experimental results indicated that two kinds of microbial agents had a remarkable remedying effect on the heavy metals; the remedying effect of $\mathrm{Cr}^{2+}$ and $\mathrm{Pb}^{2+}$ by CMA was better compared with PMA, while the remedying effect of $\mathrm{Cd}^{2+}$ and $\mathrm{Zn}^{2+}$ by PMA was better than CMA, and the remedying effect of $\mathrm{Cu}^{2+}$ was almost equally good by two kinds of microbial agents. Bud rate and growth momentum improved significantly in contaminated soil after remediation, the concentration of heavy metals in seedlings and vegetables was reduced greatly, and several heavy metals indices were lower than the national standards. For different heavy metals pollution, different microbial agents should be used: namely the CMA are suitable for remedying $\mathrm{Cr}^{2+}$ and $\mathrm{Pb}^{2+}$, whereas PMA are suitable for remedying $\mathrm{Cd}^{2+}$ and $\mathrm{Zn}^{2+}$.
\end{abstract}

Keywords: microbial agents, bioremediation, in situ, heavy metals, planting experiment

\section{Introduction}

In recent years, pollution events by heavy metals have occurred frequently, including several dozen extremely serious cases that have threatened lives [1]. Of all pollution by heavy metals, soil pollution is particular serious in that the heavy metals are very difficult to separate and degrade in soil. When entering farmland soil, heavy metals don't only have negative effects on microbial populations, population structures, and soil enzyme activity, they also degrade soil fertility and disturb the normal metabolism of

*e-mail: cxqian@seu.edu.cn crops - reducing crop yield and quality. And as a result, it does harm to people's health after these heavy metals enter human bodies via the food cycle and accumulate in their bodies $[2,3]$.

At present, there are two kinds of approaches that can remedy heavy metals in contaminated soil:

1. Cut down the total amount of heavy metals using various methods, which is mainly represented by engineering measures and phytoremediation technology.

2. Reduce the mobility and bio-availability of heavy metals in soil by changing their existing form in soil, which is mainly represented by chemical passivation technology and microbial remediation [4]. 
When remedying heavy metals in contaminated soil, engineering measures can be costly and damage the original character of soil; phytoremediation technology has a very low target biomass and long remedying circle, and it also has difficulties in consequent disposition. Therefore, the application of these two methods is confined to some extent [5-9]. However, mineralization remediation of heavy metal ions by microbial agents as a new technology is being paid extensive attention in that it has very low cost, simple operation and rapid effects, and thus is suitable for soil pollution abatement in large areas. At present, there are already some studies on microbial remediation of heavy metals.

Dhami et al. found that radioactive ${ }^{90} \mathrm{Sr}^{2+}$ can be transformed into carbonate mineral compound and co-precipitated in calcite by urease [10]. Macaskie et al. proved that a large number of hydrogen phosphate ions produced by gram-negative bacteria via phosphatase, could combine with heavy metals in the surface of bacteria, and thus produced minerals [11]. Van et al. demonstrated that sulfatereducing bacteria can reduce sulfate into sulfide, making heavy metals in soil environment produce precipitation and passivated [12]. Li et al. chose a kind of bacteria which could produce urease. When this urease hydrolyzed carbamide, it produced a large amount of carbonate mineral compound, and in this process heavy metals could be removed effectively, ranging from $88 \%$ to $99 \%$ within 48 hours [13]. However, the studies mentioned above are only implemented in labs and none has been reported to be applied to environmental protection.

This paper, based on a previous study [14-17], selected two kinds of microbial agents - carbonate-microbe agents (CMA) and phosphate-microbe agents (PMA) - which were respectively used to remedy heavy metals in contaminated soil. By this, the remedying effect, the remedying range and application scope of two kinds of microbial agents were verified.

\section{Materials and Methods}

\section{Selection of the Contaminated Soil}

The contaminated soil around a mine factory was selected as the research object. In this factory, iron ore exploited from mines was there for simple rough machining after being smashed into pieces, and then screen out valuable ore, leaving the surplus material piling around the factory. Due to such factors as rain wash, plenty of heavy metals were transplanted to the nearby farmland, which finally caused serious soil contamination.

As a research object, $100 \mathrm{~m}^{2}$ of contaminated soil was selected. Soil samples were taken in terms of the sampling standards.

\section{Analysis of the Contaminated Soil}

The selected soil samples were naturally air-dried, ground, griddled through a $0.2 \mathrm{~mm}$ sieve, and then preserved. Then one gram griddled samples were weighed pre- cisely, mixed with $8 \mathrm{~mL}\left(1 \mathrm{~mol} \cdot \mathrm{L}^{-1}\right)$ sodium acetate solution, put into a constant temperature incubator shaker at indoor temperature for $2 \mathrm{~h}$, and then centrifuged at 2,400 rpm for $20 \mathrm{~min}$. Finally, the supernatant liquor that separated from the solution was put into a polyethylene bottle. The concentration of heavy metals was analyzed in the supernatant liquor with ICP-AES (OPTIMA 2000DV).

The selected soil samples were naturally air-dried, ground up, and griddled through a $0.2 \mathrm{~mm}$ sieve. Then 5 gram soil samples were weighed precisely, mixed with $25 \mathrm{~mL}$ deionized water, and the suspension liquid was stirred continuously for $30 \mathrm{~min}$. The $\mathrm{pH}$ value was measured with a $\mathrm{pH}$ electrode (PHS-3C(A)pH meter).

\section{Analysis of the Concentration of Heavy Metals in Crops}

The crop was washed with deionized water and then was killed out for $5 \mathrm{~min}$ at $105^{\circ} \mathrm{C}$ before drying. It was dried to constant weight in a drying oven $\left(70^{\circ} \mathrm{C}\right)$ and griddled with sieves after being smashed into pieces; $5 \mathrm{~g}$ were put into a conical flask with $40 \mathrm{~mL}$ mixed acid, and then the conical flask was covered and steeped for one night. The next day we put a funnel to the bottleneck, put the conical flask on an electric hot plate to dispel until it finished frothing, and then increased the temperature to make brown smoke, which it had produced and changed into white smoke. After the white smoke around the bottleneck disappeared, if the liquid in the flask produced new white smoke it was considered a thorough chemical reaction, and the solution left in the flask was clear and colorless. We added $10 \mathrm{~mL}$ water and continued to heat it until it produced white smoke twice, and then cooled it. We then transferred the solution into a $100 \mathrm{~mL}$ volumetric flask and added water to its $100 \mathrm{~mL}$ scale. Finally, the concentration of heavy metals was analyzed with ICPAES (OPTIMA 2000DV).

\section{Composition of Microbial Agents}

Microbial agents consisted of two parts: bacteria powder and substrate. CMA were prepared by mixing carbonate-mineralization bacteria and urea in a certain proportion. Carbonate-mineralization bacteria, or bacillus, produced urease after being dissolved in water, and then urea was decomposed under the effect of urease and produced $\mathrm{CO}_{3}^{2-}$, which could mineralize free heavy metals into carbonate precipitate and realize the objective of remedying heavy metals. PMA were prepared by mixing phosphate-mineralization bacteria and glycerophosphate in a certain proportion. Phosphate-mineralization bacteria, which is also bacillus, produced alkaline phosphatase after being dissolved in water, and then glycerophosphate was decomposed under the effect of alkaline phosphatase and produced $\mathrm{PO}_{4}^{3-}$, which could mineralize free heavy metals into phosphate precipitate and thus prevent heavy metals from removing freely. According to the previous research results, the optimal proportion was: the bacteria powder (g): substrate (g): water $(\mathrm{L})=2: 25: 1$. 


\section{Dosage of Microbial Agents}

The dosage of microbial agents depended on the concentration of heavy metals in contaminated soil while being influenced by the environmental $\mathrm{pH}$ value and temperature, as well as soil type. The service conditions of microbial agents are as follows: $\mathrm{pH}$ value higher than 5 , temperature ranging $10-35^{\circ} \mathrm{C}$.

The total content of heavy metals is obtained according to the following equation:

$$
M=\sum_{i} \frac{\rho V C_{i}}{M_{i}}
$$

...where $M$ is the total content of heavy metals in contaminated soil $(\mathrm{mmol}), \rho$ is the soil density $\left(\mathrm{kg} \cdot \mathrm{m}^{-3}\right), V$ is the total volume of the contaminated soil $\left(\mathrm{m}^{3}\right), C_{i}$ is the concentration of heavy metals $\left(\mathrm{mg} \cdot \mathrm{kg}^{-1}\right), M_{i}$ is the relative atomic mass of a heavy metals $\left(\mathrm{g} \cdot \mathrm{mol}^{-1}\right)$, and $i$ signifies $\mathrm{Pb}^{2+}, \mathrm{Cd}^{2+}$, $\mathrm{Zn}^{2+}, \mathrm{Cu}^{2+}$, and so on.

The dosage of substrate is equal to the total content of heavy metals, namely $\sum_{i} \frac{\rho V C_{i}}{M_{i}}$ (mmol), and the mass is taken as:

$$
m_{s}=M_{s} \sum_{i} \frac{\rho V C_{i}}{M_{i}} \times 10^{-3}
$$

...where $m_{s}$ is the dosage of substrate $(\mathrm{g})$ and $M_{s}$ is the relative molecula mass of substrate $\left(\mathrm{g} \cdot \mathrm{mol}^{-1}\right)$.

According to the optimal proportion from previous research, the dosage of bacteria powder and the dosage of water are given respectively as:

$$
\begin{aligned}
& m_{j}=0.0800 \times M_{s} \sum_{i} \frac{\rho V C_{i}}{M_{i}} \times 10^{-3} \\
& V_{w}=0.0400 \times M_{s} \sum_{i} \frac{\rho V C_{i}}{M_{i}} \times 10^{-3}
\end{aligned}
$$

...where $m_{j}$ is the dosage of bacteria powder $(\mathrm{g})$ and $V_{w}$ is the dosage of water (L).

\section{Use of Microbial Agents}

Firstly, the powder of CMA and PMA were put into water for six hours to make them revive, and then added the substrate into the solution that could be used after it dissolved completely. In order to sprinkle evenly and increase the penetration depth of microbial agents in contaminated soil, it could be diluted before sprinkling.

\section{Representation of the Remedying Effect}

The remedying effect by microbial agents could be represented via the mineralization rate of heavy metals. In other words, it could be represented by comparing the change of concentration of heavy metals before and after remediation. The mineralization rate of heavy metals is obtained according to the following equation:

$$
I=1-C_{2} / C_{1}
$$

...where $I$ is the mineralization rate of heavy metals, $C_{1}$ is the concentration of heavy metals before remediation by microbial agents $\left(\mathrm{mg} \cdot \mathrm{kg}^{-1}\right)$, and $C_{2}$ is the concentration after remediation by microbial agents $\left(\mathrm{mg} \cdot \mathrm{kg}^{-1}\right)$.

\section{Results and Discussion}

\section{Remedying Effect of Heavy Metals in Contaminated Soil}

It was planned that the selected contaminated soil would be remedied by using CMA and PMA, respectively, with the planned remediation depth $20 \mathrm{~cm}$ and soil density $1,100\left(\mathrm{~kg} \cdot \mathrm{m}^{-3}\right)$. During the experiment the environmental temperature was about $25^{\circ} \mathrm{C}$ and the $\mathrm{pH}$ value of selected soil was 6 (faintly acidic). According to the computing method, the dosage of microbial agents was calculated; soil sample after remediation was taken back and concentration of heavy metals in effective state was analyzed. The change of concentration of heavy metals is shown in Table 1 .

As shown in Table 1, one week after sprinkling microbial agents the concentration of heavy metals in effective state significantly decreased, which indicated that CMA and PMA both remedied heavy metals effectively. The remedying effect of $\mathrm{Cr}^{2+}$ and $\mathrm{Pb}^{2+}$ by CMA was better compared with PMA, while the remedying effect of $\mathrm{Cd}^{2+}$ and $\mathrm{Zn}^{2+}$ by PMA was better than CMA, and that of $\mathrm{Cu}^{2+}$ was almost equally good by two different microbial agents. Such differences were caused by the fact that heavy metals may have different inhibiting effects on the enzymatic activity of CMA and PMA.

Thus it could be seen that different heavy metals should be remedied by different microbial agents. To be specific, CMA are more suitable for remedying the contamination caused by $\mathrm{Cr}^{2+}$ and $\mathrm{Pb}^{2+}$, while PMA are more suitable for remedying the contamination caused by $\mathrm{Cd}^{2+}$ and $\mathrm{Zn}^{2+}$.

\section{Cultivating Green Vegetable Seeds Experiment after Remediation}

In order to confirm the remedying effect clearly, a cultivating experiment of green vegetable seeds was conducted. Soil samples were taken as the non-remedied soil (A), soil (B) (remedied by CMA), and soil (C) (remedied by PMA). To make the experiment more convenient, an illumination incubator was adopted for pot experiment, and 100 seeds were cultivated in each pot.

The incubator condition was simulation physical condition - $12 \mathrm{~h}$ light and $12 \mathrm{~h}$ dark - while keeping the air circulating. During the experiment, three pots were exposed to the same cultivating condition. The growing situation of seedlings (including bud rate, plant height, lamina color and more), were recorded. Seedling growth and concentration of heavy metals in seedlings are respectively shown in Fig. 1 and Table 2. 
Table 1. Remedying effect of heavy metals in contaminated soil by CMA and PMA.

\begin{tabular}{|l|c|c|c|c|c|}
\hline \multicolumn{1}{|c|}{ Soil samples } & $\mathrm{Cr}^{2+}$ & $\mathrm{Pb}^{2+}$ & $\mathrm{Cd}^{2+}$ & $\mathrm{Zn}^{2+}$ & $\mathrm{Cu}^{2+}$ \\
\hline Concentrations of heavy metals before remediation $\left(\mathrm{mg} \cdot \mathrm{kg}^{-1}\right)$ & 4.76 & 3.72 & 0.15 & 10.74 & 4.70 \\
\hline Concentrations of heavy metals after remediation by CMA $\left(\mathrm{mg} \cdot \mathrm{kg}^{-1}\right)$ & 0.92 & 0.95 & 0.07 & 5.32 & 1.28 \\
\hline Mineralization rate by CMA (\%) & 80.67 & 74.46 & 53.33 & 50.47 & 72.77 \\
\hline Concentrations of heavy metals after remediation by PMA $\left(\mathrm{mg} \cdot \mathrm{kg}^{-1}\right)$ & 2.41 & 1.13 & 0.04 & 2.13 & 1.24 \\
\hline Mineralization rate by PMA (\%) & 49.37 & 69.62 & 73.33 & 80.17 & 73.62 \\
\hline
\end{tabular}

As shown in Fig. 1, seeds in three pots all grew into seedlings. Of the three, seedlings in soils $\mathrm{B}$ and $\mathrm{C}$ both grew relatively well, but seedlings in soil A began to wither soon, for the reason that heavy metals had a negative effect on them. Through analysis of seedling bud rate after 30 days, it was comparatively high in the soil remedied by CMA and PMA, while the bud rate was comparatively low in nonremedied soil, which indicated that heavy metals restrained the bud and growth of seedlings to a certain extent. As shown in Table 2, concentrations of heavy metals in seedlings were significantly lower in the soil remedied by CMA and PMA than its concentrations in non-remedied soil. The concentration of $\mathrm{Cd}^{2+}$ remedied by CMA and PMA, the concentration of $\mathrm{Cr}^{2+}$ remedied by PMA, and the concentration of $\mathrm{Pb}^{2+}$ remedied by CMA are all lower than domestic relative standards.
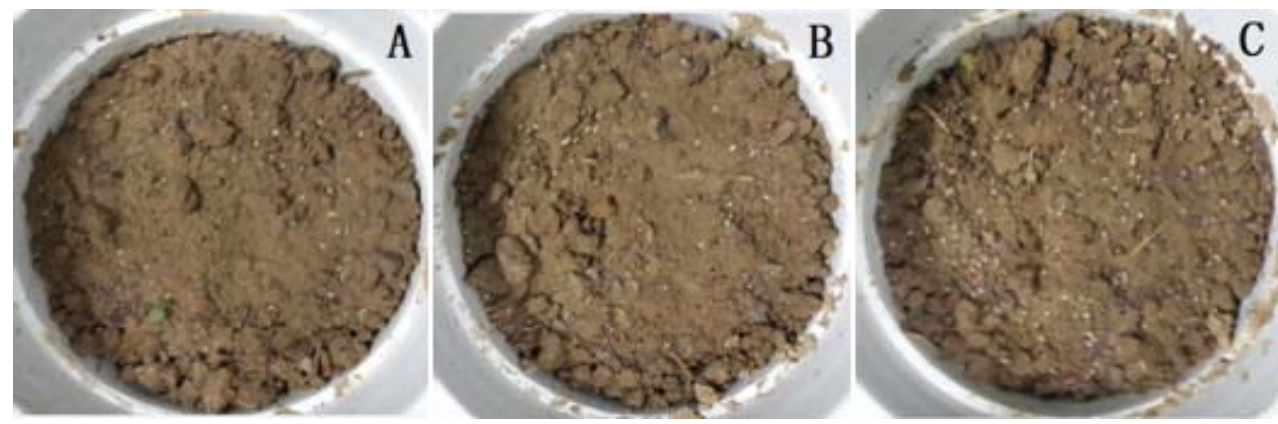

(1) Seedlings' growing situation on $5^{\text {th }}$ day
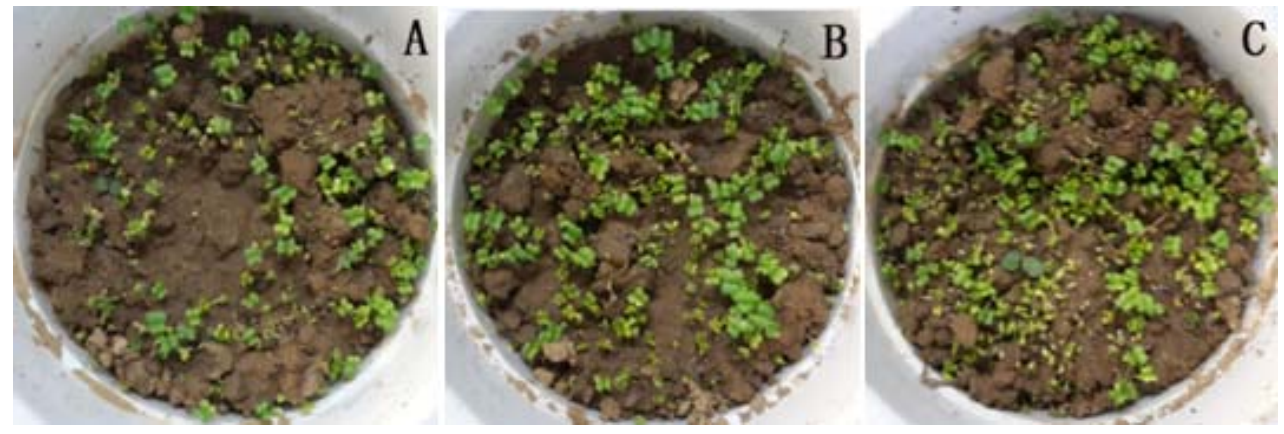

(2) Seedlings' growing situation on $10^{\text {th }}$ day
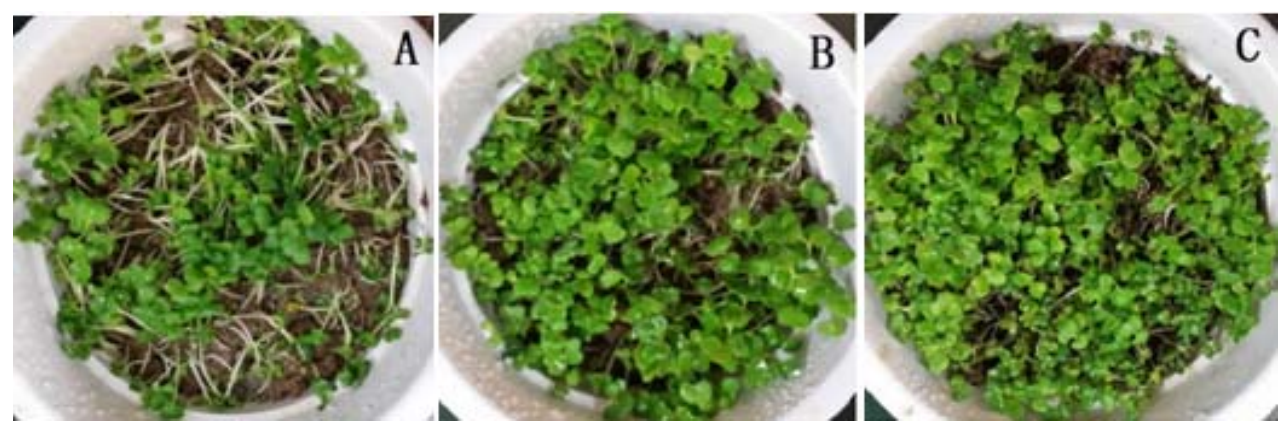

(3) Seedlings' growing situation on $30^{\text {th }}$ day

Fig. 1. Seedlings' growing situation in different growing time and planting condition 
Table 2. Concentrations of heavy metals in seedlings in different methods.

\begin{tabular}{|c|c|c|c|c|c|}
\hline \multirow{2}{*}{ Soil samples } & $\mathrm{Cr}^{2+}$ & $\mathrm{Pb}^{2+}$ & $\mathrm{Cd}^{2+}$ & $\mathrm{Zn}^{2+}$ & $\mathrm{Cu}^{2+}$ \\
\cline { 2 - 6 } & \multicolumn{5}{|c|}{$\left(\mathrm{mg} \cdot \mathrm{kg}^{-1}\right)$} \\
\hline $\mathrm{A}$ & 5.38 & 2.96 & 0.15 & 43.67 & 10.22 \\
\hline $\mathrm{B}$ & 1.06 & 0.24 & 0.08 & 16.81 & 2.06 \\
\hline $\mathrm{C}$ & 0.88 & 0.31 & 0.03 & 14.84 & 2.12 \\
\hline $\begin{array}{c}\text { Domestic relative } \\
\text { standards }\end{array}$ & 0.50 & 0.30 & 0.1 & $/$ & $/$ \\
\hline
\end{tabular}

Transplanting Experiment of Vegetables after Remediation

Vegetables that grew in contaminated soil were respectively transplanted to three pots: the non-remedied soil (a), the soil (b) remedied by CMA, and the soil (c) remedied by PMA. After they continued to grow in different soil for some time, the remedying effect could be figured out by researching the change of concentration of heavy metals. The growing situation of contaminated vegetables in different times is shown in Fig. 2, and concentration of heavy

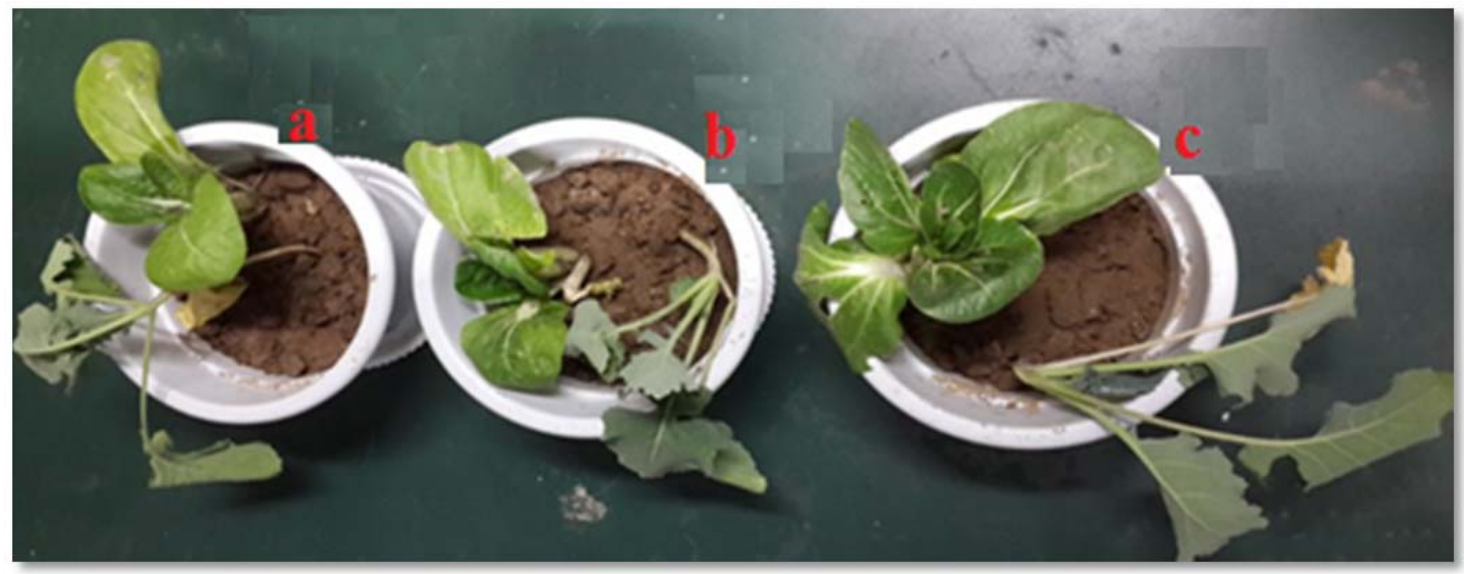

(1) Vegetables' growing situation on $5^{\text {th }}$ day

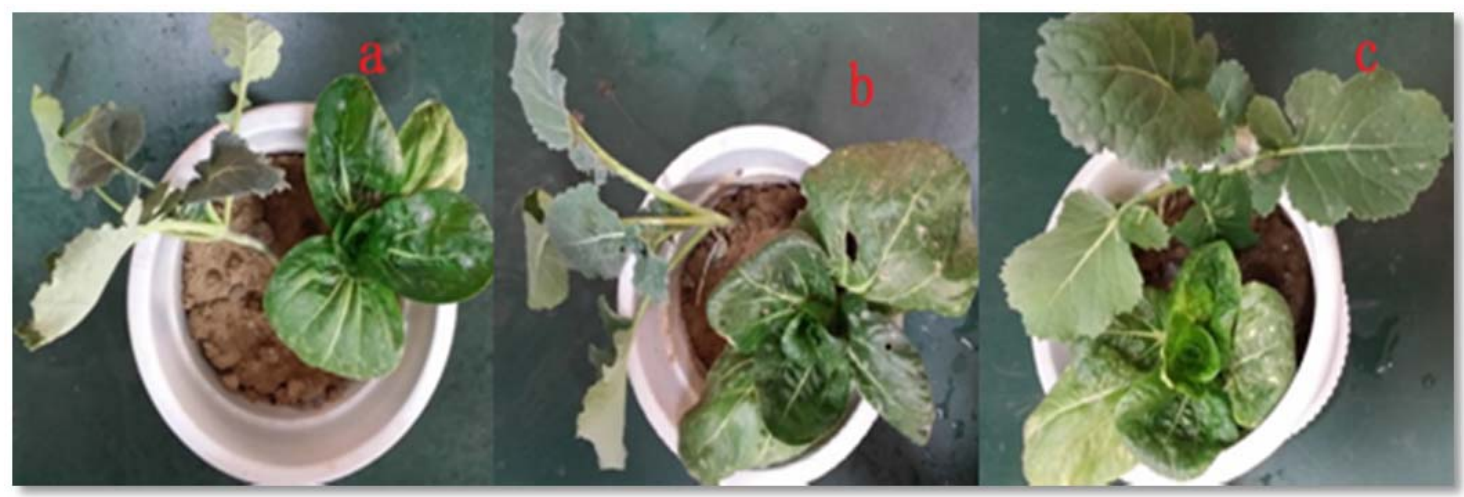

(2) Vegetables' growing situation on $10^{\text {th }}$ day

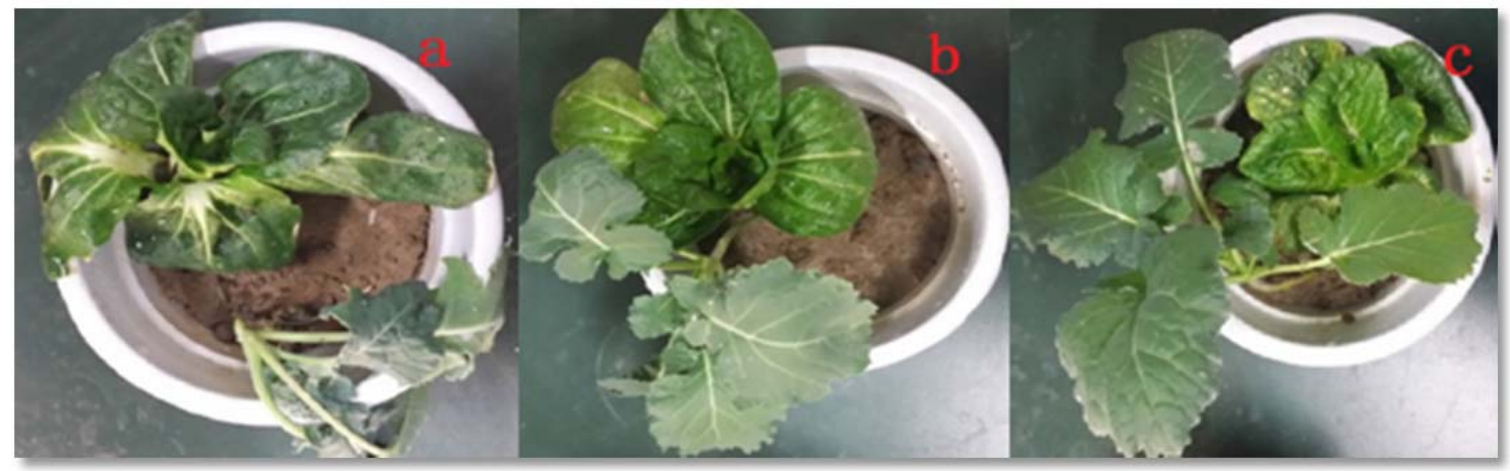

(3) Vegetables' growing situation on $30^{\text {th }}$ day

Fig. 2. Vegetables' growing situation in different growing time and planting condition. 
Table 3. Concentrations of heavy metals in vegetables remedied using experiment different methods.

\begin{tabular}{|c|c|c|c|c|c|}
\hline \multirow{2}{*}{ Soil samples } & $\mathrm{Cr}^{2+}$ & $\mathrm{Pb}^{2+}$ & $\mathrm{Cd}^{2+}$ & $\mathrm{Zn}^{2+}$ & $\mathrm{Cu}^{2+}$ \\
\cline { 2 - 6 }$\left(\mathrm{mg} \cdot \mathrm{kg}^{-1}\right)$ \\
\hline $\mathrm{a}$ & 9.62 & 5.54 & 0.26 & 64.23 & 14.02 \\
\hline $\mathrm{b}$ & 1.36 & 0.82 & 0.11 & 24.32 & 4.26 \\
\hline $\mathrm{c}$ & 0.98 & 1.02 & 0.08 & 14.84 & 4.15 \\
\hline $\begin{array}{c}\text { Domestic relative } \\
\text { standards }\end{array}$ & 0.50 & 0.30 & 0.1 & $/$ & $/$ \\
\hline
\end{tabular}

metals in vegetables remedied in different methods is shown in Table 3.

Fig. 2 indicates that vegetables' growing situations were similar in different growing times and planting conditions. After 30 days, vegetables in soil (a) began to wither with lamina very light, while those in soils (b) and (c) grew very well with a distinct vein of lamina. After 30 days, vegetables were taken out and concentration of heavy metals in them was measured (Table 3). It can be seen in Table 3 that concentrations of heavy metals in vegetables growing in remedied soil significantly decreased, and quite a few indexes were lower than domestic relative standards.

\section{Conclusions}

This paper investigated the remedying effect of heavy metals by CMA and PMA, while green vegetable cultivation and the vegetable transplanting experiment were conducted in a comparative way in soil that had been remedied by two different microbial agents. From the experiments, conclusions could be drawn: two kinds of microbial agents had remarkable remedying effect of the heavy metals; the remedying effect of $\mathrm{Cr}^{2+}$ and $\mathrm{Pb}^{2+}$ by CMA was better compared with PMA, while the remedying effect of $\mathrm{Cd}^{2+}$ and $\mathrm{Zn}^{2+}$ by PMA was better than CMA, and that of $\mathrm{Cu}^{2+}$ was almost equally good by two different microbial agents. Bud rate and growth momentum improved significantly in contaminated soil after remediation, and the concentration of heavy metals in seedlings and vegetables reduced greatly, while several heavy metals indices were lower than the domestic relative standards. For different heavy metals pollution, different microbial agents should be used: namely CMA are suitable for remedying $\mathrm{Cr}^{2+}$ and $\mathrm{Pb}^{2+}$, whereas PMA are suitable for remedying $\mathrm{Cd}^{2+}$ and $\mathrm{Zn}^{2+}$. Thus, this method should be popularized on a large scale and applied to contaminated soil.

\section{Acknowledgements}

This work was supported financially by the National Nature Science Foundation of China (Grant No. 51372038) and the Jiangsu Province 333 Project.

\section{References}

1. JIANG N. Heavy metal pollution hazard. Environmental Economy 10, 10, 2011.

2. CHEN L., SONG Y.F., ZHANG W., LI X.Y., WANG L., JI P.H., YANG X.X. Assessment of toxicity effects for cadmium contamination in soils by means of multi-indexes. Environmental Science 29, 2606, 2008.

3. TENG Y., LUO Y.M., LI Z.G. Kinetics characters of soil urease, acid phosphotase and dehydrogenase activities in soil contaminated with mixed heavy metals. China Environmental Science 28, 147, 2008.

4. LI J.R., XU Y.M., LIN D.S., LIANG X.F., SUN Y.B., WANG L. In situ immobilization remediation of heavy metals in contaminated soils: A review. Ecology and Environmental Sciences 23, 721, 2014.

5. CUI D.J., ZHANG Y.L. Current situation of soil contamination by heavy metals and research advances on the remediation techniques. Chinese Journal of Soil Science 35, 366, 2004.

6. PROBSTEIN R.F., HICK R.E. Removal of contaminants from soils by electric fields. Science 260, 498, 1993.

7. KAWACHI T., KUBO H. Model experimental study on the migration behavior of heavy metals in electtokinetic remediation process for contaminated soil. Journal of Soil Science and Plant Nutrition 45, 259, 1999.

8. TAMPOURIS S., PAPASSIOPI N.I. Removal of contaminant metals from fine grained soil using agglomeration chloride solutions and pileleaching techniques. J. Hazard. Mater. B84, 297, 2001.

9. PICHTEL J., PICHTEL T.M. Comparison of solvents for ex situ removal of chromium and lead from contaminated soil. Environ. Eng. Sci. 14, 97, 1997.

10. DHAMI N.K., REDDY M.S., MUKHERJEE A. Biomineralization of calcium carbonates and their engineered applications:a review. Frontiers in Microbiology 4, 13, 2013.

11. MACASKIE L.E., DEAN A.C.R., CHEETHAM A.K., JAKEMAN R.J.B., SKARNULIS A.J. Cadmium accumulation by a Citrobacter sp:the chemical nature of the accumulated metal precipitate and its location on the bacterial cells. J. Gen. Microbiol. 133, 539, 1987.

12. VAN R.S., VANBROEKHOVEN K., DEJONGHE W., DIELS L. Immobilization of heavy metals in the saturated zone by sorption and in situ bioprecipitation processes. Hydrometallurgy 83, 195, 2006.

13. LI M., CHENG X.H., GUO H.X. Heavy metal removal by biomineralization of urease producing bacteria isolated from soil. Int. Biodeter. Biodegr. 76, 81, 2013.

14. WANG R.X., QIAN C.X., WU M. Study on heavy metals in soil mineralized by bacteria. Journal of Functional Materials 38, 1523, 2007.

15. CHENG L., QIAN C.X., WANG R.X. Bioremediation process of $\mathrm{Cd}^{2+}$ removal from soil by bacteria A biomineralization. Journal of the Chinese Ceramic Society 36, 215, 2008.

16. CHENG L., QIAN C.X. Advances in the research of mechanism of biomineralizing calcium carbonate. Bulletin of the Chinese Ceramic Society 25, 108, 2006.

17. WANG M.M., QIAN C.X. Study on heavy metal ion $\mathrm{Zn}^{2+}$ mineralized by phosphate ore implication of bacteria. Journal of Functional Materials 44, 393, 2013. 